\title{
KARAKTER TINGGI TANAMAN, UMUR PANEN, JUMLAH ANAKAN DAN BOBOT PANEN PADA 14 GENOTIPE PADI LOKAL
}

\author{
Nopia Yulina ${ }^{1}$, Chairil Ezward*2, A. Haitami ${ }^{2}$ \\ ${ }^{1}$ Mahasiswa Program Studi Agroteknologi \\ ${ }^{2}$ Dosen Program Studi Agroteknologi \\ Fakultas Pertanian Universitas Islam Kuantan Singingi \\ *Email : ezwardchairil@yahoo.com
}

\begin{abstract}
ABSTRAK
Penelitian ini bertujuan untuk mengevaluasi karakter agronomi seperti tinggi tanaman, umur panen, jumlah anakan dan bobot panen 14 genotipe padi lokal (Oryza sativa. L). Penelitian ini dilaksanakan di Desa Petapahan, Kecamatan Gunung Toar, Kabupaten Kuantan Singingi, pada bulan November 2019 hingga Maret 2020. Rancangan yang digunakan adalah Rancangan Acak Kelompok (RAK) dengan 14 perlakuan yang berasal dari genotipe padi lokal. Hasil penelitian menunjukkan pengaruh genotip yang nyata terhadap tinggi tanaman, umur panen, dan jumlah anakan. Hasil tinggi tanaman terbaik adalah PL04 (148,42 cm), umur panen PL07 (99 Hari Setelah Tanam) dan jumlah anakan PL07 (9,26 batang). Sedangkan rendemen tidak menunjukkan pengaruh yang signifikan. Kegunaan penelitian ini sebagai informasi awal untuk mengetahui karakter agronomi padi lokal. Sehingga nantinya dapat dipertimbangkan atau digunakan untuk pengembangan benih padi.
\end{abstract}

Kata kunci : Karakter agronomi, padi lokal

\section{ABSTRACT}

This research aimed to evaluate agronomical characterssuch as plant height, harvest age, number of tillers and harvest weight of 14 genotypes of local rice (Oryza sativa. L). This research was conducted in Petapahan Village, Gunung Toar District, Kuantan Singingi Regency, from November 2019 to March 2020. The design used was a randomized completely block design (RCBD) with 14 treatments in from of local rice genotypes. The result showed a significant effect of genotipy on plant height, harvest age, and number of tillers. The best result of plant height was PL04 (148. $42 \mathrm{~cm})$, harvesting age was PL07 (99 Days After Planting) and the number of tillers was PL07 (9.26 stems). Meanwhile the yield showed no significant effect. The use of this research is as initial information to determine the agronomic character of local rice. So that later it can be considered or used for the development of rice seeds.

Keywords : Agronomic character, local rice

\section{PENDAHULUAN}

Padi atau beras merupakan tanaman pangan sebagai sumber energi yang umumnya di konsumsi oleh rakyat Indonesia. Hampir separuh penduduk dunia terutama Asia menggantungkan hidupnya dari tanaman padi. Hal ini dikarenakan Beras sebagai pangan yang bermanfaat yang kaya akan nutrisi seperti asam amino, kalium magnesium, 
kalsium, zat besi, pigmen antosianin sehingga dapat meningkatkan daya tahan tubuh terhadap penyakit, memperbaiki sel hati, mecegah gangguan fungsi ginjal, mencegah kangker dan mencegah anemia (Suhartini dan Suardi, 2010).

Oleh karena itu beras telah menjadi bagian dari kehidupan masyarakat Indonesia sehingga tidak dapat dipungkiri bahwa komoditas ini telah turut mempengaruhi tatanan politik dan stabilitas nasional. Padi juga telah menjadi sumber mata pencarian sebagian besar petani di perdesaan. Produksi padi perlu ditinggkatkan dan dikembangkan untuk memenuhi kebutuhan pangan penduduk yang terus bertambah dan juga mengembangkan kembali varietas padi lokal (Purwono dan Heni, 2009).

Keuntungan lain dalam menggunakan varietas lokal adalah lebih tahan dengan cekaman lingkungan karena adaptasinya tidak luas (spesifik lokasi), telah mengikuti selera konsumen, hasil lebih stabil bila dibandingkan dengan varietas unggul.

Hal ini dapat terjadi karena kondisi cuaca di Kabupaten Kuantan Singingi umumnya sedikit ekstrim. Apabila hujan dapat menimbulkan banjir disawah dan akan menyebabkan penanaman akan diulang. Apabila panas dapat menimbulkan terlambatnya pemindahan bibit ke lahan sawah. Kedua hal ini berpengaruh terhadap penghasilan petani. Contoh beberapa varietas yang di akui oleh masyarakat seperti varietas padi singgam putih, padi kuning dan padi merah.

Kabupaten Kuantan Singingi (Kuansing) merupakan salah satu Kabupaten yang menghasilkan beras di Propinsi Riau. Kuansing merupakan salah satu daerah yang potensial untuk budidaya tanaman padi (Ezward, et al (2017).

Oleh karena itu penelitian ini bertujuan untuk mengetahui karakter tinggi tanaman, umur panen, jumlah anakan, dan berat panen empat belas genotipe padi lokal (Oryza sativa. L) Kabupaten Kuantan Singingi.

Karena setiap genotipe lokal memilik sifat dan peciri yang berbeda tergantung sifat genetiknya masing-masing. Sehingga perlu dilakukan karakteristik dan identifikasi pada padi lokal untuk menjadi pertimbahan dalam pengembangan varietas dan biodiversiti padi.

Hasil eksplorasi dan identifikasi penelitian sebelumnya (Chairil et al, 2019), telah menemukan beberapa genotipe yang terdapat di Kabupaten Kuantan Singingi, selanjutnya genotipe genotipe tersebut menarik untuk dilakukan eksperimen dengan melihat potensi hasilnya. Kabupaten Kuantan Singingi memiliki banyak genotipe lokal yang mungkin orang belum mengetahui adanya perbedaan setiap genotipenya. Maka dari itu perlu dilakukan uji genotipe terhadap tinggi tanaman, umur panen, jumlah anakan dan berat panen.

\section{METODE PENELITIAN}

Penelitian ini telah dilakukan di Desa Petapahan Kecamatan Gunung Toar Kabupaten Kuantan Singingi. Sejak bulan November 2019 sampai Maret 2020.

Bahan yang digunakan dalam penelitian ini adalah genotipe padi Sironda putih (PL01), saronda merah (PL02), Pandan wangi F4 (PL03), pulut hitam (PL04), ronda putiah (PL05), singgiro merah (PL06), kuning umur panjang (PL07), padi ros (PL08), samo putiah (PL09), limbayang (PL10), pulut karate (PL11), sokan umur panjang (PL12), pulut benai Peboun Hulu (PL13), singgam putih (PL14).

Penelitian ini menggunakan Rancangan Acak Kelompok Non Faktorial yang terdiri dari 14 Genotipe perlakuan (padi lokal) dimana masing- 
masing perlakuan terdiri dari 3 ulangan. Dengan demikian penelitian ini terdiri dari 42 unit percobaan. Setiap unit percobaan terdiri dari 9 tanaman dan 7 diantaranya dijadikan tanaman sampel. Jarak tanam yang digunakan adalah $30 \mathrm{x}$ $30 \mathrm{~cm}$.

Data hasil penelitian yang diperoleh dari lapangan di analisis secara statistik sesuai dengan Rancangan Acak Kelompok Rak Non Faktorial dengan rumus sebagai berikut :

$$
Y \mathbf{i j k}=\mu+\mathbf{k}+\alpha \mathbf{i}+\mathbf{\varepsilon i j}
$$

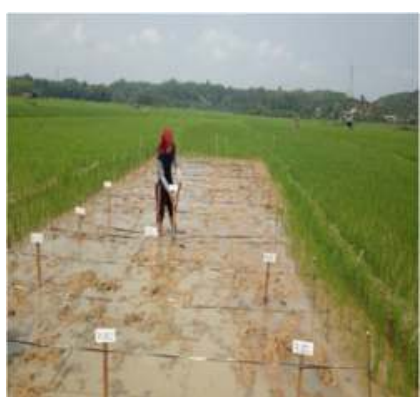

Gambar 1. Pemasangan Label

\section{PelaksanaanPenelitian}

Menurut Purwasasmita (2002), adapun tahapan-tahapan dalam persiapan bibit adalah sebagai berikut : Seleksi benih, perendaman benih, persemaian benih. Selanjutnya pengolahan lahan, pembuatan plot, pemasangan label, pemberian pupuk kotoran ayam, penanaman bibit, dan pemberian pupukan organik.

\section{Parameter Pengamatan}

\section{Tinggi Tanaman (cm)}

Pengukuran tinggi tanaman dilakukan pada tanaman sampel. Pengukuran tinggi tanaman dilakukan dengan cara mengukur tanaman mulai dari leher akar sampai ujung daun yang tertinggi (diurut keatas). Dengan menggunakan penggaris, pengamatan ini dilakukan mulai pada umur 14 hari setelah tanam sampai munculnya bunga dengan interval 1 minggu sekali sampai dengan 8 kali pengukuran hingga umur 86 hari.

\section{Umur Panen (hari setelah tanam)}

Pengamatan umur panen dilakukan dengan cara menghitung waktu padi mulai ditanam setelah masa persemaian sampai padi dipanen, dengan melihat kriteria panen pada tanaman padi setiap plot yang telah mencapai $75 \%$.

\section{Jumlah Anakan (batang)}

Pengamatan jumlah anakan dihitung pada tanamansampel dengan cara mengamati dan menghitung anakan baru, pengamatan dilakukan pada akhir penelitian.

\section{Berat Gabah Panen (ton/hektar)}

Berat gabah panen padi dihitung dengan cara menimbang padi pada saat panen di setiap plot. Kemudian dijumlahkan setiap ulangannya lalu dicari nilai rata-rata perplot.

\section{HASIL DAN PEMBAHASAN}

Berdasarkan data hasil pengamatan terhadap parameter tinggi tanaman, setelah dilakukan sidik ragam. Menunjukkan bahwa perlakuan genotipe memberikan pengaruh nyata terhadap tinggi tanaman. Berdasarkan uji lanjut BNJ pada taraf 5\% hasil rerata tinggi tanaman dapat dilihat pada tabel 1.

Berdasarkan hasil Uji Lanjut BNJ dengan taraf $5 \%$ dapat dilihat bahwa perlakuan genotipe memberikan pengaruh yang nyata terhadap tinggi tanaman. Genotipe padi lokal yang memiliki parameter tertinggi yaitu PL04 (Pulut Hitam). 
Tabel 1. Rerata tinggi tanaman perlakuan 14 genotipe padi lokal umur 86 (HST)

\begin{tabular}{ll}
\hline GENOTIPE $($ PL) & Rerata $(\mathrm{cm})$ \\
\hline PL01 : Sirondah Putiah & $126,79 \mathrm{bcd}$ \\
PL02 : Sironda Merah & $121,99 \mathrm{bcde}$ \\
PL03 : Padi Pandan Wangi & $109,09 e$ \\
PL04 : Pulut Hitam & $148,42 \mathrm{a}$ \\
PL05 : Padi Ronda Putiah & $126,37 \mathrm{bcd}$ \\
PL06 : Padi Singgiro Merah & $113,61 \mathrm{de}$ \\
PL07 : Padi Kuning & $134,18 \mathrm{bc}$ \\
PL08 : Padi Ros & $146,71 \mathrm{a}$ \\
PL09 : Padi Samo Putiah & $130,80 \mathrm{bc}$ \\
PL10 : Padi Limbayang & $120,85 \mathrm{cde}$ \\
PL11 : Pulut Karate & $146,64 \mathrm{a}$ \\
PL12 : Padi Sokan & $118,7 \mathrm{cde}$ \\
PL13 : Pulut Benai & $112,78 \mathrm{de}$ \\
PL14 : Padi Singgam Putiah & $135,51 \mathrm{ab}$ \\
\hline KK $=6,45 \%$ & $\mathrm{BNJ}=14,24$ \\
\hline
\end{tabular}

Keterangan: Nilai rata rata yang diikuti oleh hurufkecil yang sama pada baris yang berbedamenunjukanperbedaan yang tidaknyataberdasarkan uji BNJ pada taraf alpha 5\%

Perlakuan genotipe ini tidak berbeda nyata dengan perlakuan genotipe PL11 (Pulut Karate), PL08 (Padi Ros), PL14 (Singgam Putih) tetapi berbeda nyata dengan perlakuan genotipe PL09 (Samo Putiah), PL07 (Padi kuning umur panjang), PL01 (Sironda Putiah), PL02 (Sarondah Merah), PL03 (Pandan Wangi) PL05 (Ronda Putiah), PL06 (Singgaro Merah), PL10 (Limbayang), PL12 (Sokan Umur Panjang), PL13 (Pulut Benai).

Pada genotipe PL04 (Pulut Hitam) merupakan tinggi tanaman tertingg yang memiliki tinggi tanaman $148,42 \mathrm{~cm}$, sedangkan genotipe yang memiliki tinggi tanaman paling rendah yaitu terdapat pada genotipe PL03 (Padi Pandan wangi) yaitu $109,9 \mathrm{~cm}$. Hal ini disebabkan karena sifat genetik yang memiliki karakter atau peciri yang berbeda. Sehingga genotipe yang berbeda akan berbeda pula tinggi tanamannya.

Menurut Hartati et al. ,(2012), keragaman yang tinggi pada fase generatif menunjukkan bahwa karakter lebih banyak dipengaruhi oleh faktor genetik. Sesuai dengan Suprihatno (2010) bahwa tinggi rendahnya batang tanaman dipengaruhi sifat atau ciri yang mempengaruhi daya hasil varietas. Dan juga variasi tinggi tanaman yang terjadi antar varietas disebabkan karena setiap genotipe memiliki faktor genetik dan karakter yang berbeda (Efendi, 2012).

Selain itu, adanya perbedaan karakter genotipe yang tampak masing-masing genotipe disebabkan oleh adanya perbedaan gen yang mengatur karakter tersebut. Hal ini sesuai dengan pendapat Yatim (1991), bahwa setiap gen memiliki pekerjaannya masing-masing untuk menumbuhkan dan mengatur berbagai jenis karakter dalam tubuh organisme.

Perbedaan susunan genetik merupakan salah satu faktor penyebab keragaman penampilan tanaman dalam hal ini tinggi tanaman. Hal ini sesuai dengan pendapat Mildaerizanti, (2008) bahwa perbedaan tinggi tanaman lebih ditentukan oleh faktor genetik. Disamping dipengaruhi oleh faktor genetik, juga dipengaruhi oleh kondisi lingkungan tumbuh tanaman. Apabila lingkungan tumbuh sesuai bagi pertumbuhan tanaman maka dapat meningkatkan produksi tanaman. Keadaan lingkungan yang bervariasi dari suatu tempat ketempat lain dan kebutuhan tanaman akan keadaan 
lingkungan yang khusus akan mengakibatkan keragaman pertumbuhan tanaman. Selanjutnya Vaughan (1994) menambahkan bahwa karakter tinggi tanaman sangat dipengaruhi oleh faktor lingkungan.

Kondisi lingkungan pada semua genotipe mendapatkan perlakuan yang sama, sehingga faktor genetik lebih beperan dalam perbedaan tinggi tanaman. Hal ini sesuai dengan pendapat Gardner, et al (1991) yang menyatakan bahwa pertumbuhan dan perkembangan tanaman dipengaruhi oleh faktor genetik dan lingkungan. Selanjutnya Suriwinoto (1982), menyatakan bahwa tinggi tanaman padi merupakan sifat keturunan dari masing masing genotipe.
Menurut Wahyuni penggunaan benih dari genotipe yang berbeda akan memberikan potensi yang berbeda dan perbedaan ini akan menimbulkan keragaman penampilan. Hal ini juga dikatakan oleh Martono (2009), karakter yang rendah sampai sedang menandakan bahwa faktor lingkungan lebih berpengaruh dari faktor genetik.

Data hasil pengamatan tinggi tanaman padi pada tabel 5 dapat dilihat laju pertumbuhan yang memperlihatkan uji 14 Genotipe padi lokal yang memberikan pengaruh terhadap tinggi tanaman dapat dilihat pada gambar 2 .

\section{Laju pertumbuhan tinggi tanaman $(\mathrm{cm})$}

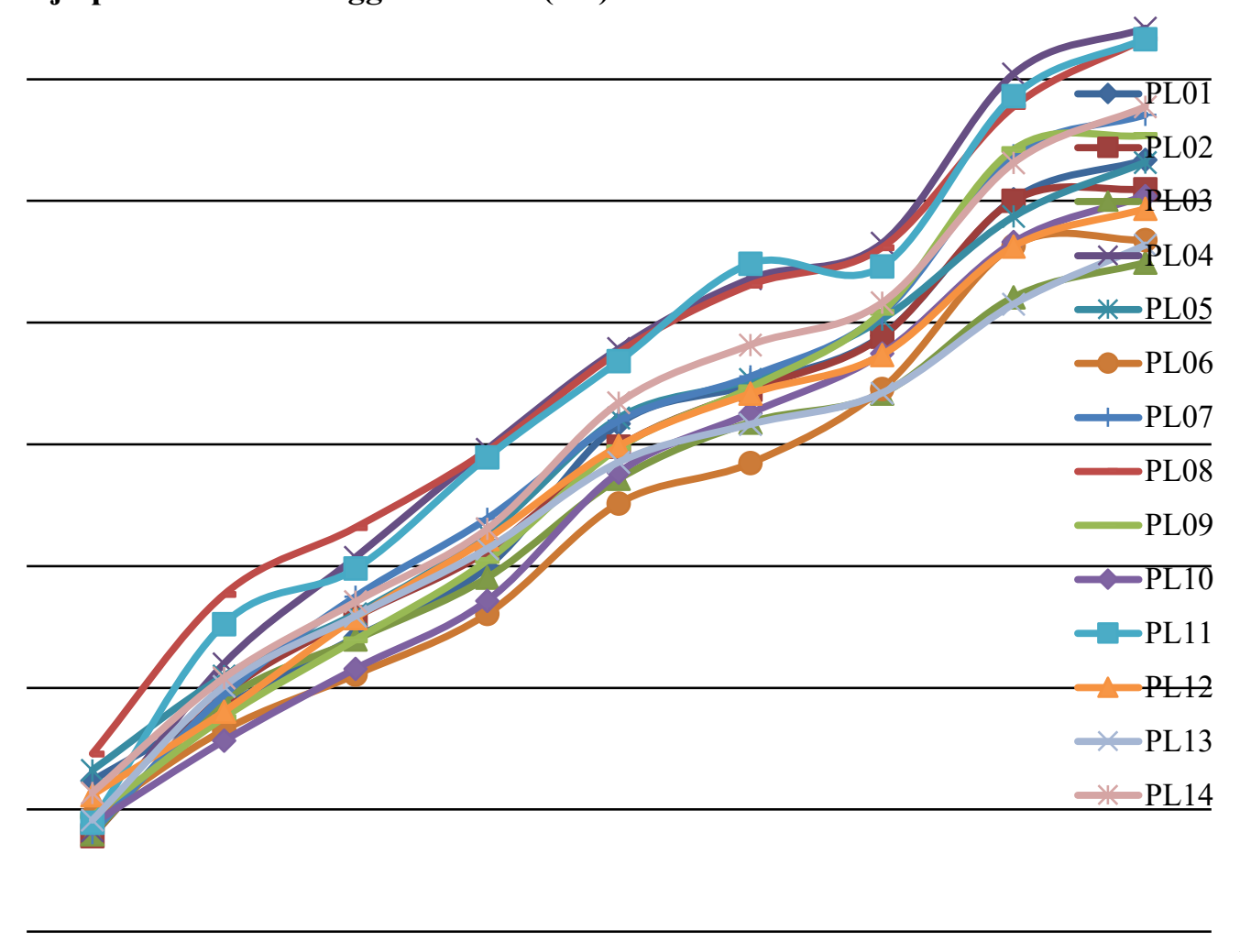

Gambar 2. Grafik laju pertumbuhan tinggi tanaman terhadap 14 varietas padi lokal.

Berdasarkan gambar 1 dapat dilihat laju pertumbuhan tinggi tanaman terhadap berbagai varietas padi lokal dari awal tanam hingga minggu ke 9 yaitu sampai munculnya bunga dan malai.
Genotipe yang memiliki perbedaan laju pertumbuhan yang berbeda-beda. Disini bisa kita lihat laju pertumbuhan genotipe PL04 yang pada awal tanam yaitu pemindahan bibit dari media semai 
kelahan penelitian dengan tinggi tanaman $16,6 \mathrm{~cm}$ dan 1 minggu setelah tanam dengan tinggi tanaman $43,99 \mathrm{~cm}$ dan minggu selanjutnya $61,52 \mathrm{~cm}$ hingga sampai minggu ke 9 dengan tinggi tanaman 148,42 cm, dapat kita lihat laju pertumbuhan tinggi tanaman padi yang di sebabkan faktor genetik masing-masing genotipe.

\section{Umur Panen (HST)}

Berdasarkan data hasil pengamatan terhadap parameter umur panen, setelah dilakukan sidik ragam. Menunjukkan bahwa perlakuan genotipe memberikan pengaruh nyata terhadap parameter umur panen. Rerata umur panen tanaman padi setelah diuji dengan BNJ pada taraf 5\% dapat dilihat pada tabel 2 .

Tabel 2. Rerata umur panen perlakuan 14 genotip padi lokal

\begin{tabular}{ll}
\hline GENOTIPE (PL) & Rerata \\
\hline PL01 : Sirondah Putiah & $121,33 b$ \\
PL02 : Sironda Merah & $125,67 b c$ \\
PL03 : Padi Pandan Wangi & $123,67 b$ \\
PL04 : Pulut Hitam & $138,00 e$ \\
PL05 : Padi Ronda Putiah & $111,66 a$ \\
PL06 : Padi Singgiro Merah & $126,00 \mathrm{~cd}$ \\
PL07 : Padi Kuning & $99,00 a$ \\
PL08 : Padi Ros & $121,33 b$ \\
PL09 : Padi Samo Putiah & $128,00 \mathrm{~d}$ \\
PL10 : Padi Limbayang & $129,00 \mathrm{de}$ \\
PL11 : Pulut Karate & $122,00 \mathrm{~b}$ \\
PL12 : Padi Sokan & $120,00 \mathrm{~b}$ \\
PL13 : Pulut Benai & $114,67 a b$ \\
PL14 : Padi Singgam Putiah & $113,00 a$ \\
\hline KK = 1,8\% & BNJ=3,93 \\
\hline Keterangan : Nilai rata rata yang diikuti oleh hurufkecil yang sama pada baris yang \\
\multicolumn{1}{c}{ berbedamenunjukanperbedaan yang tidaknyataberdasarkan uji BNJ pada } \\
$\quad$ taraf alpha 5\%.
\end{tabular}

Berdasarkan tabel 2 diatas menunjukkan bahwa perlakuan genotipe memberikan pengaruh yang nyata terhadap umur panen. Pada genotipe yang memiliki umur panen paling cepat terdapat pada genotipe PL07 (padi kuning), perlakuan ini tidak berbeda nyata dengan PL05 (Padi Ronda Putiah), PL13 (Padi Pulut Benai), PL14 (Padi Singgam Putiah) tetapi berbeda nyata dengan genotipe PL01 (Sironda Putiah), PL02 (Sironda Merah), PL03 (Pandan Wangi), PL04 (Pulut Hitam), PL06 (Singgiro Merah), PL08 (Padi Ros), PL09 (Padi Samo Putiah), PL10 (Padi Limbayang), PL11 (Pulut Karate) dan PL12 (Padi Sokan).
Genotipe yang umur panen cepat terdapat pada PL07 yaitu 99 Hari, sementara genotipe yang memiliki umur panen yang paling lama adalah PL04 (Pulut Hitam) yaitu 138 Hari. Hal ini diduga oleh faktor genetik yang memiliki karakter sifat gen yang berbeda setiap genotipenya.

Padi hitam tergolong padi yang berdaya hasil rendah, berumur panjang, dan peka terhadap perubahan kondisi alam (Dewi dan Purwoko 2010). Umur tanaman berhubungan dengan faktor genetis tanaman, itulah sebabnya mengapa tiap genotipe yang di uji memiliki umur tanaman yang berbeda. Hal ini seperti yang dikemukan oleh Masdar et al. (2006), tanaman akan 
memperlihatkan matang panen jika total energi yang diadopsi sudah mencapai batas taraf tertentu dan batas taraf tertentu berbeda-beda pada masingmasing tanaman umumnya disebabkan oleh faktor genetis.

Menurut Mangoendidjo (2003), penampilan suatu tanaman pada lingkungan tertentu merupakan hasil interaksi faktor lingkungan dan genetik. Dalam hal ini faktor genetik yang lebih dominan mempengaruhi umur muncul bunga dan umur panen dibandingkan lingkungan.

Menurut Putih et al. (2011), yang membedakan umur berbunga setiap genotip adalah faktor genetiknya. Cockram et al. (2007), menyatakan aktivitas gen yang mengendalikan waktu berbunga hingga menjadi umur panen yaitu dipengaruhi oleh lingkungan penanaman.
Perbedaan ini disebabkan oleh faktor genetik yang dimiliki oleh masingmasing genotipe, berdasarkan lamanya fase vegetatif. Menurut Yuhelmi (2002) meningkatkan pertumbuhan vegetatif dan meningkatkan pertumbuhan ke arah pemkembangan bunga dan pembentukan buah.

\section{Jumlah Anakan ( Batang)}

Data hasil pengamatan terhadap jumlah anakan tanaman padi setelah dianalisis sidik ragam memperlihatkan uji berbagai genotipe padi lokal menunjukkan bahwa perlakuan genotipe memberikan pengaruh yang nyata terhadap jumlah anakan tanaman padi. Rata-rata jumlah tanaman padi setelah diuji dengan $\mathrm{BNJ}$ pada taraf $5 \%$ dapat dilihat pada tabel 3 .

Tabel 3. Rerata jumlah anakan perlakuan 14 genotipe padi lokal

\begin{tabular}{ll}
\hline GENOTIPE (PL) & Rerata (Batang) \\
\hline PL01 : Sirondah Putiah & $6,31 \mathrm{def}$ \\
PL02 : Sironda Merah & $7,89 \mathrm{abcd}$ \\
PL03 : Padi Pandan Wangi & $8,08 \mathrm{abcd}$ \\
PL04 : Pulut Hitam & $7,82 \mathrm{abcde}$ \\
PL05 : Padi Ronda Putiah & $8,77 \mathrm{ab}$ \\
PL06 : Padi Singgiro Merah & $7,23 \mathrm{bcdef}$ \\
PL07 : Padi Kuning & $9,26 \mathrm{a}$ \\
PL08 : Padi Ros & $6,72 \mathrm{cdef}$ \\
PL09 : Padi Samo Putiah & 6,00 ef \\
PL10 : Padi Limbayang & $5,77 \mathrm{f}$ \\
PL11 : Pulut Karate & $7,53 \mathrm{abcdef}$ \\
PL12 : Padi Sokan & $8,18 \mathrm{abcd}$ \\
PL13 : Pulut Benai & $9,02 \mathrm{ab}$ \\
PL14 : Padi Singgam Putiah & $8,34 \mathrm{abc}$ \\
\hline KK $=12,1 \%$ & $\mathrm{BNJ}=1.88$ \\
\hline KL
\end{tabular}

Keterangan: Nilai rata rata yang diikuti oleh hurufkecil yang sama pada baris yang berbedamenunjukanperbedaan yang tidaknyataberdasarkan uji BNJ pada taraf alpha 5\%

Berdasarkan tabel 3 menunjukkan bahwa perlakuan genotipe memberikan pengaruh nyata terhadap jumlah anakan tanaman padi. Perlakuan yang memiliki jumlah anak terbanyak terdapat pada genotipe PL07 (Padi Kuning) perlakuan ini tidak berbeda nyata dengan genotipe
PL02 (Sirondah Merah), PL03 (Padi Pandan Wangi), PL04 (Pulut Hitam), PL05 (Padi Ronda Putiah), PL11 (Pulut Karate), PL12 (Padi Sokan), PL13 (Pulut Benai), PL14 Padi Singgam Putiah), tetapi berbeda nyata dengan PL01 (Sirondah Putiah), PL06 (Sirondah 
Merah), PL08 (Padi Ros), PL09 (Padi Samo Putiah), PL10 (Padi Limbayang).

Genotipe yang memberikan hasil terbanyak pada parameter jumlah anakan terdapat pada genotipe PL07 (Padi Kuning) yaitu 9,26 batang anakan produktif, sementara genotipe yang memiliki jumlah anakan produktif paling sedikit adalah PL10 (Padi Limbayang) yaitu 5,77 batang anakan produktif. Hal ini karena dipengaruhi sifat genetik. Dimana sifat gen, peciri atau karakter padi lokal yang memiliki jumlah anakan yang termasuk memiliki jumlah anakan kurang.

Menurut Zen et al. (2002), anakan produktif dapat dikelompokkan atas tiga tipe, yaitu anakan kurang (kurang dari 12 batang per rumpun), anakan sedang (1320 batang per rumpun) dan anakan banyak (lebih dari 20 batang per rumpun). Dari hasil pengamatan yang dilakukan, secara umum semua kultivar yang di uji termasuk kelompok yang memiliki anakan produktif kurang.

Hal ini dikarenakan bahwa setiap masing-masing genotipe berbeda dalam menghasilkan jumlah anakan yang disebabkan oleh faktor genetik dari masing-masing genotipe yang memiliki ciri dan sifat khusus genetik yang merupakan salah satu penyebab keragaman penampilan tanaman serta akibat dari adaptasi genotipe terhadap lingkungan dalam menghasilkan anakan. Menurut Arrudeau dan Vergara (1992), kemampuan masing-masing varietas berbeda dalam menghasilkan anakan, hal ini disebabkan oleh faktor genetik yang dimiliki dari masing-masing varietas juga berbeda-beda.

Menurut Husna (2010) jumlah anakan akan maksimal apabila tanaman memiliki sifat genetik yang baik ditambah dengan keadaan lingkungan yang menguntungkan atau sesuai dengan pertumbuhan dan perkembangan tanaman. Selain ditentukan oleh faktor lingkungan perbedaan pertumbuhan tanaman juga dipengaruhi oleh faktor gen yang dimiliki oleh masing-masing genotip tersebut (Gardner et al. , 1991).

Menurut Supriadin et al. (2013), perbedaan jumlah anakan yang terjadi bisa karena faktor genetik ataupun lingkungan seperti curah hujan, teknik budidaya, jarak tanaman, serta ketersedian hara.

\section{Berat Panen (gram/rumpun)}

Data hasil pengamatan terhadap berat panen setelah dianalisis ragamyang menunjukkan bahwa perlakuan genotip tidak berpengaruh nyata terhadap berat panen. Berdasarkan uji lanjut BNJ pada taraf 5\% hasil rerata berat panen dapat dilihat pada tabel 4 .

Berdasarkan tabel 4 diatas menunjukkan bahwa perlakuan genotipe setelah dilakukan uji lanjut BNJ pada taraf 5\% tidak memberikan pengaruh yang nyata terhadap berat panen. Hal ini dikarena genotipe yang digunakan adalah genotipe yang belum mampu memberikan respon terhadap berat panen.

Pada perlakuan genotipe berat panen yang paling berat terdapat pada perlakuan PL14 (Padi Singga Putiah) yaitu 1,84 ton/ha. Sedangkan yang paling rendah terdapat pada perlakuan PL11 (Pulut Karate) yaitu 1,32 ton/ha. Walaupun perlakuan ini tidak memberikan pengaruh yang nyata namun hasil terbaik terdapat pada PL14 yaitu 1,4 ton/ha. Hal ini diduga oleh faktor genetik dan lingkungan sehingga belum mampu memberikan respon pada berat panen tanaman padi.

Sesuai dengan pernyataan Senewe dan Alfons (2011), perbedaan produksi dapat disebabkan oleh komposisi genetik dari masing-masing kultivar padi. Selain genetik, faktor lingkungan juga berpengaruh pada produksi tanaman padi. 
Tabel 4. Rerata berat panen perlakuan 14 genotipe padi lokal

\begin{tabular}{lc} 
GENOTIPE (PL) & Rerata (gram) \\
\hline PL01 : Sirondah Putiah & 13,88 \\
PL02 : Sironda Merah & 15,78 \\
PL03 : Padi Pandan Wangi & 12,47 \\
PL04 : Pulut Hitam & 12,84 \\
PL05 : Padi Ronda Putiah & 16,46 \\
PL06 : Padi Singgiro Merah & 12,06 \\
PL07 : Padi Kuning & 13,36 \\
PL08 : Padi Ros & 12,81 \\
PL09 : Padi Samo Putiah & 12,59 \\
PL10 : Padi Limbayang & 14,48 \\
PL11 : Pulut Karate & 11,93 \\
PL12 : Padi Sokan & 15,28 \\
PL13 : Pulut Benai & 12,65 \\
PL14 : Padi Singgam Putiah & 16,57 \\
\hline
\end{tabular}

$\mathrm{KK}=17,9 \%$

Keterangan: Nilai rata rata yang diikuti oleh hurufkecil yang sama pada baris yang berbedamenunjukanperbedaan yang tidaknyataberdasarkan uji BNJ pada taraf alpha $5 \%$

Perbedaan genetik dari masingmasing genotipe yang menjadi penyebab perbedaan hasil atau produksi. Hal ini sesuai dengan pernyataan Kamal (2001), perbedaan produksi disebabkan komposisi genetik pada masing-masing kultivar padi sehingga respon lingkungan berbeda.

\section{KESIMPULAN}

Perbedaan genotipe memberikan pengaruh yang nyata terhadap karakter tinggi tanaman, umur panen dan jumlah anakan. Hasil tertinggi pada karakter tinggi tanaman terdapat pada PL04 (Pulut Hitam) yaitu $148,21 \mathrm{~cm}$, umur panen terdapat pada PL07 (Padi Kuning) yaitu 99 hari dan jumlah anakan terbaik juga terdapat pada PL07 (Padi Kuning) yaitu 9,26 batang. Tetapi tidak berpengaruh nyata terhadap berat panen. Manfaat penelitian ini sebagai informasi karakter agronomi padi lokal Kuantan Singingi. Sehingga nantinya dapat dipertimbangkan atau digunakan untuk pengembangan benih padi.

\section{DAFTAR PUSTAKA}

Arraudeau. M. A dan B. S Vergara, 1992. Pedoman Budidaya Padi Gogo. BPTP. Sukarami.

Cockram J. H jones, FJ Leigh, D O'Sullivan, W Powell DA Laurie and AJ Greenland, 2007. Control of flowering time in temperate cereals; genes domestication, and sustainable productivity. Journal of experimental botany 58, 1231-1244

Dewi IS dan Purwoko BS. 2010. Kultur antera untuk mendukung tanaman padi. Bul. Agron 29 (2) : 59-63.

Effendi S. 2012. Metode Penelitian Survei Jakarta. LP3ES

Ezward C, Elfi I, Seprido dan Mashadi. 2017. Peningkatan Produktivitas Tanaman Padi melalui Teknik Budidaya dan Pupuk Kompos Jerami. Agrosains dan Teknologi Volume 2 Nomor 1, hlm 51-68

Ezward. C, Irfan. S, Nalwida. R, Indra. D. 2019. Eksplorasi Keragaman Plasma Nutfah Padi Lokal Kuantan Singing berdasarkan Morfologi Gabah dan Beras. Un publish

Gardner FP, Pearce RB, and Mitchell RL. 1991. Physiology of Crop Plants. Di 
terjemahkan oleh H. Susilo. Universitas Indonesia Press. Jakarta.

Hartati, S. ,A. Setiawan, B. Heliyanto, dan Sudarsono. 2012. Keragaman genetik, heritabilitas dan korelasi antar karakter 10 genotipe terpilih jarak pagar (Jatrotpa curcas L. ). J. Littri. 8(2):74-80.

Husna, Y. 2010. Pengaruh Penggunaan Jarak Tanam terhadap Pertumbuhan dan Produksi Padi Sawah (Oryza sativa L. ) Varietas IR42 dengan Metode SRI (System Of Rice Intensification). Jurnal. Jurusan Agroteknologi. Fakultas Pertanian. Universitas Riau. Vol 9. Hal 2-7.

Kamal, F. 2001. Parameter Genetik Beberapa Galur Introduksi Padi Sawah (Oryza sativa, L) [skripsi]. Fakultas Pertanian Universitas Andalas Padang,

Mangoendidjojo W. 2003 Dasar Dasar Pemuliaan Tanaman. Kanisius. Yogyakarta.

Masdar, M. Karim, B. Rusman, N. Hakim dan Helmi. 2006. Tingkat Hasil Dan Komponen Hasil Sistem Intensifikasi Padi (SRI) Tampa Pupuk Organik Di Daerah Curah Hujan Tinggi. Jurnal Ilmu-Ilmu Pertanian Indonesia. Volume 8, No. 2, 2006. Hal 126-131.

Martono B 2009. Keragaman Genentik, Heribilitas dan Korelasi Antar Karakter Kuantitatif Nilam (Pogostemon $s p$. ) Hasil fusi Protoplas. Jurnal Littri. 15 (1) ; 9 15.

Mildaerizanti. 2008. Keragaman Beberapa Varietas Padi Gogo di Daerah aliran sungai Batang hari. http:// katalog. pustaka-deptan. go. id/ jambi/getfile2.

php? $\mathrm{src}=2008 /$ pros53f. psf\&format $=$ application/pdf.

Purwasasmita . 2002. Padi SRI Organik Indonesia. Penebar Swadaya. Jakarta. 136-138 hal.

Purwono, L., dan Heni Purnawati. 2009. Budidaya 8 Jenis Tanaman Pangan Unggul, Penebar Swadaya. Jakarta.

Putih R, Anwar A,GR NAR. 2011. Variabilitas Genetik Karakter Umur,
Hasil, Dan Komponen Hasil Beberapa Genotipe Padi Lokal (Oryza sativa L,. ) Sumatera Barat. Seminar Nasional : Reformasi Pertanian Terintegrasi Menuju Kedaulatan Pangan. Jakarta. Terjemahan Susilo H. Hal 155 dan 269.

Senewe R. E dan J. B Alfons. 2011. Adaptasion Stydy of Several Varietas of Wet Land Rice Production Centers in West Seram Maluku Province. Jurnal Budidaya Pertanian, Vol. 7. No 2, Desember 2011, Halaman 60,64

Suhartini, T. dan D. Suardi. 2010. Potensi beras lokal Indonesia. Warta Penelitian dan Pengembangan Pertaniaan. 32 (1) : 9-10.

Supriadin, Ete A. Made U. 2013. Karakteristik Genotipe Padi Gogo Lokal Asal Kabupaten Banggal. J. Agrotekbis 1 (5) : 443 - 450.

Suprihatno, B,. Daradjat, A. A,. Satoto. , Baehaki, S. E. , Suprihatno,. Setyono, A. S, D. I. I, P. W,. Sembiring, H. 2010. Deskripsi Varietas padi. Balai Besar Penelitian Tanaman Padi. Badan Penelitian dan Pengembangan Pertanian Departemen Pertanian.

Suriwinoto S. 1982. Budidaya Tanaman Padi. Gramedia Pustaka. Jakarta.

Vaughan, T. 1994. Multimedia : Making it work (2nd ed). USA : McGraw-Hill

Wahyuni, S. 2008. Hasil Padi Gogo dari Dua Sumber Benih yang Berbeda. Penelitian Pertanian Tanaman Pangan. 27 (3)

Yatim, W. 1991. Genetika. Tarsito. Bandung

Yuhelmi, R 2002. Pengaruh Interval Penyiraman Terhadap Padi Gogo dari Kabupaten Kuantan Singingi dan Siak Sri Indrapura. Skripsi Fakultas Pertanian Universitas Riau (tidak dipublikasikan)

Zen, S., Zarwan, H. ,Bahar. , Dasmal, F. , Artati, Aswardi dan Taufik, 2002. Pengkajian varietas padi sawah spesifik preferensi konsumen Sumatera Barat. Balai Pengkajian Teknologi, Sumatera Barat. 